\title{
Introduction: a discipline in crisis?
}

\section{An Identity Crisis}

Traditional legal scholarship is under pressure. In several countries around the world, a debate has evolved about the aims and methods of the academic study of law. There are various aspects to this debate. One question is, what should legal academics be concerned with: the traditional study of legislation and case law and its accommodation in the legal 'system' (an activity that is increasingly regarded as lacking in creativity), or with much more elevated themes? Another question is about the methods that should be used in legal research and how this research should be assessed, prompting the question, which research is 'better' and why should this be the case? There have also been pleas to organize the legal discipline more in line with other fields, including the introduction of rigorous peer review and the classification of journals. Finally, some have made the claim that legal academics should also be substantively more oriented towards other fields (in particular the social sciences) and that legal scholarship should develop as an international discipline instead of one primarily dealing with only one national law.

This debate is taking place in several European countries and, in particular, in the United Kingdom and the Netherlands. According to Becher $(1989,30)$, legal academics are seen by their other colleagues in the university as 'not really academic. (. . .) Their scholarly activities are thought to be unexciting and uncreative, comprising a series of intellectual puzzles scattered along "large areas of description". Twining $(1994,141)$ characterizes the traditional academic approach to law as 'narrow, conservative, illiberal, unrealistic and boring', with too much attention 
being given to technical details and too little to the 'big' questions. In the Netherlands, the discussion is at least partly the result of the financial consequences attached to the uncertain status of the legal discipline: lawyers often have difficulty in convincing representatives of other disciplines, university administrators and funding organizations of the quality of their work. See, for a similar debate in Germany: Ipsen (2005), Engel \& Schön (2007), and Bernhart (2008); and for a general perspective on methodology, Van Hoecke (2011). In France, a related discussion is taking place about the merits of doctrinal work: see Jestaz \& Jamin (2004); Pimont (2006); and Muir-Watt (2011). Van Gestel and Micklitz (2011) make the claim that doctrinal legal research should be revitalized.

The debate about the aims and methods of legal scholarship is not limited to Europe. While, in several European countries, the academic study of law is often seen as not academic enough, the usual criticism in American law schools is that there is too much attention to theory and interdisciplinarity in teaching and research.

The starting point for this debate in the United States is arguably the well-known article written by Judge Harry T. Edwards (1992), in which he fulminates about the gap between legal practice and the, in his view, often irrelevant and mediocre interdisciplinary work published in the more prestigious law reviews. In addition, he argued that future lawyers will no longer receive an adequate legal education that prepares them to practice law as the national law schools have been moving towards educating academics instead of lawyers. According to Edwards (1992, 56), however, " "personal fascination" is not a justification for scholarship, of any kind'. Deborah Rhode $(2002,1340)$ also complains that too much legal research is not done well: 'it exhaustively exhumes unimportant topics or replicates familiar arguments on important ones'.

Although the debate about aims and methods of academic work in law has received new impetus in the last decade, it is not a new discussion. At least since the beginning of the 
nineteenth century, the tocsin has sounded over the status of the legal discipline. Well-known are the cries of distress by Von Kirchmann ('The Worthlessness of Jurisprudence as a Body of Knowledge') in 1848 and by Lundstedt ('The NonAcademic Character of the Legal Discipline') in 1932. In the Netherlands, it was Taco Mulder who, in 1937, published a brochure with the title 'I Accuse the Faculty of Law of Being Non-Academic'. While the arguments of these authors are diverse, they all enter into combat with traditional legal scholarship.

The plea of Von Kirchmann in 1848 best fits the present discussion: its main point is that legal science differs from most other academic disciplines because it is the 'maid of the coincidence' as it primarily deals with solving uncertainties and gaps in the positive law. This makes jurists - in Von Kirchmann's figurative language - like worms that live only from the putrid wood in the positive law, in his view a situation fatal to the academic character of jurisprudence. In his famous words: 'As the science makes the coincidental its article, it becomes coincidental itself; three words changed by the law-maker, and whole libraries become rubbish' (p. 24).

Lundstedt's criticism on the other hand is inspired by a specific (empirical) view of science: because legal academics deal with justice, and justice is not an observable phenomenon, it is not real science. The only thing possible is then a 'positive science of law' (Adolf Merkel). Others (including those adhering to Austin's analytical legal philosophy), however, have fundamentally disputed this view of what makes a field academic.

It is important to make clear what this criticized 'traditional' legal science is really about. The criticism is usually directed to the doctrinal approach, in which rules, principles and case law are considered from the internal perspective and in which law is looked at as being in a relatively autonomous relation to the social, economic and political reality. It is the positive law as given by legislatures and courts that forms the starting point for any meaningful analysis. This positive law can of course 
be criticized, but legal academia accepts the bulk of it as given and legal practice itself can profit from doctrinal criticism and systematization. The search for coherence in the given materials is thus seen as an important, if not the most important, part of academic work.

McCrudden (2006, 633) recently described traditional legal science as a discipline of 'critical reasoning based around authoritative texts'. Two aspects are important to emphasize. The first is the central role of legislature and the courts: their decisions can be criticized, but in the end their texts do have authority. Cf. Posner (1990, 83): 'To be blunt, the ultimate ratio of law is indeed force' and the classic statement by Hobbes in A Dialogue Between a Philosopher and a Student of the Common Laws of England (1681, [2005, 55]): 'It is not wisdom, but authority that makes a law.' The second aspect is that this doctrinal approach has its own methodology. Even though it may not be clear what this legal methodology exactly consists of (it entails a certain way of interpretation, systematization and argumentation), there is little doubt that it is an autonomous methodology: reference to other than the own, legal, sources is not needed. Cf. Posner (2002, $1316)$ and Ibbetson $(2003,864)$, and for the internal perspective also infra, no. 10 .

\section{Legal Science at the Crossroads}

The arguments made above substantiate the conclusion that the legal discipline suffers from an identity crisis: not only do outsiders accuse legal science of being unacademic, but also legal scholars themselves no longer seem to know which discipline they practice. This crisis is surprising. A midlife crisis it cannot be: the academic study of law has existed since the very founding of the University in the Middle Ages. What is more, empirical science itself originally derived its methods from the law, through scholars like Francis Bacon. In the nineteenth century, legal science was seen as one of the most important achievements of human civilization and even superior to many other academic disciplines. 
This was not only true for continental Europe but also in the Anglo-American world. David Dudley Field (1859, 13-14) thus stated about legal scholarship: 'Compare this science with any of the other sciences; with those which are esteemed the greatest in extent, and the most exalted in subject. Take even astronomy, that noble science (. . ). Sublime as this science is, it is but the science on inanimate matter, and a few natural laws; while the science which is the subject of our discourse governs the actions of human beings, intelligent and immortal, penetrates into the secrets of their souls, subdues their wills, and adapts itself to the endless variety of their wants, motives and conditions'.

The image that the outside world has of legal academics is apparently no longer based on these (or other) merits. The general tendency is to say that 'real' knowledge cannot be based upon conceptual constructions, the finding of coherence, or the development of abstract theories (all important parts of the 'internal' approach to law) but should rest on empirical work instead. This was well expressed by the famous theoretical physicist, Richard Feynman, when he deemed experiment to be 'the sole judge of scientific truth'. Although this debate about the nature of academic work has been in existence since the seventeenth century, it seems that law is now much more influenced by empiricism than it was in the past.

One result of this influence is that we now also see a shift from traditional legal scholarship towards a more interdisciplinary and empirical approach. It seems that legal science is at a crossroads in its long career. As Thomas Ulen states: 'Legal scholarship is on the verge of a dramatically different manner of doing routine legal investigation. Put in a nutshell, that change is to make law much like the other disciplines in the university that believe themselves to be practicing "science" (. . .)' What Ulen describes has already largely materialized in the United States and is seen by many as an attractive way forward for Europe as well.

See Feynman (1964) and Ulen (2002, 2); cf. Stolker (2003) for the Netherlands and Cownie $(2004,72)$ for the United Kingdom. 
This begs the question to what extent the traditional, doctrinal, method of doing academic work in law can survive if other methods of research can claim more recognition from the academic community. Empirical and interdisciplinary work in law (including 'law and ...' approaches) already has a clearly higher status in the United States than doctrinal work. The locus classicus for a survey of this development is Posner (1987). This also means that law is increasingly becoming the domain of economists, philosophers, sociologists and psychologists. McCrudden $(2006,641)$ sees this development even as ' (. . ) the growth of an approach to law that may challenge the idea of legal scholarship as a separate craft'. See also, for a possible explanation of this development, Lawrence Lessig (2011).

\section{A Rediscovery of the Legal Approach?}

The previous sections provide the background for this book. The main question addressed in the following section is whether traditional legal science is an autonomous discipline and, if so, to what extent. Moreover, the question is asked, what are the aims and methods of traditional work in law and how do they relate to other academic approaches to law and to other fields (such as economics and empirical sciences)? The answer requires an extensive discussion of various aspects of present academic practice as well as a more personal vision of what legal research should be about. This means that the argument put forward in this book is rather personal.

This book is difficult to categorize. It deals with aspects of legal theory, legal methodology and the sociology of science, but also with positive law and policy questions. Examples come mainly (but not exclusively) from the field of private law.

The main thesis of this book is that the development sketched above, in which external approaches towards law get the upper hand, is a dangerous one. There is little doubt that the law can profit from the insights of other disciplines. However, this does not mean that the normative approach towards law 
should be abandoned. On the contrary: the core question should not be how other disciplines can help us in making the academic study of law more 'scientific' but how the legal approach itself can better meet the expectations that one may have of an academic discipline. Put in a somewhat paradoxical manner: there is every reason to rediscover the legal approach to the law.

The idea that legal academics should primarily look at other disciplines for a recalibration of their field is widespread. Richard Posner is closely associated with this view. Cf. infra, no. 25 .

\section{Structure of the Argument}

Before discussing my own view of what legal science is about, it is useful to describe the various types of legal scholarship that are feasible. Chapter I describes these types of research by looking at their aims and methodology. Chapter II is devoted to what is, in my view, the main aim of legal scholarship: to reflect upon the normative question of what the law ought to be. Chapter III builds upon this view by going into the accompanying methodology. To conclude, Chapter IV is devoted to a discussion of the main consequences of this view for the organization of legal research and teaching, and for the value of creative research and methodology. The synopsis revisits the claim that legal science is in a state of crisis: the arguments presented throughout the book will allow us to exhibit a definitive answer to the question and to the extent of the predicament. 